\title{
Synthesis and Characterization of Cross Linked Acetoguanamine Polymer Complexes: Investigation of their Thermal and Magnetic Properties
}

\author{
Gurkan Guney, ${ }^{1}$ Saban Uysal ${ }^{2, \star}$ and Ziya Erdem $\operatorname{Koc}^{3}$ \\ ${ }^{1}$ University of Karabuk, Institue of Natural and Applied Sciences, Department of Polymer Engineering, \\ 78050 Karabuk, Turkey \\ ${ }^{2}$ University of Karabuk, Faculty of Science, Department of Chemistry, 78050 Karabuk, Turkey \\ ${ }^{3}$ University of Selcuk, Faculty of Science, Department of Chemistry, 42075 Konya, Turkey \\ * Corresponding author: E-mail: sabanuysal@karabuk.edu.tr \\ $\mathrm{Tel}+9(0532) 3033035$
}

Received: 09-12-2019

\begin{abstract}
In this study, 2,4-diamino-6-methyl-1,3,5-triazine (acetoguanamine) was used as the starting material. 2,4-diamino-6-methyl-1,3,5-triazine was boiled under reflux with glutaraldehyde and terephthaldehyde in acetonitrile. And, s-triazine-containing polymer ligands (IV and V) were obtained by these condensation reactions. These target s-triazin containing polymer ligands we obtained were analyzed by ${ }^{1} \mathrm{H}-\mathrm{NMR}$, FT-IR and elemental analysis. Then, polymeric metal $\left(\mathrm{Co}^{2+}, \mathrm{Ni}^{2+}\right.$ and $\left.\mathrm{Cu}^{2+}\right)$ complexes of the polymeric ligands (VI-XI) were obtained from the interaction with $\mathrm{CoCl}_{2} \cdot 6 \mathrm{H}_{2} \mathrm{O}$, $\mathrm{NiCl}_{2} \cdot 6 \mathrm{H}_{2} \mathrm{O}$ and $\mathrm{CuCl}_{2} \cdot 2 \mathrm{H}_{2} \mathrm{O}$ at $60^{\circ} \mathrm{C}$ in ethyl alcohol. The structures of these complexes were also illuminated and elucidated using FT-IR, elemental analysis and magnetic susceptibility analysis. The polymerization degrees of the polymeric ligands were determined by the molecular weight determination study with the viscometer.
\end{abstract}

Keywords: Acetoguanamine; s-triazine; Schiff bases; cross-linked polymeric complexes; thermal decomposition; magnetic properties.

\section{Introduction}

In recent years, an important class of compounds consisting of substituted s-triazine derivatives has been a growing interest in the using of s-triazine derivatives in different fields. ${ }^{1,2}$ The remarkable reactivity and unique structure of the s-triazine moiety attracted the researchers to utilize it in the modification and construction of new materials. ${ }^{3} \mathrm{~s}$-Triazine based polymers have a high transparency and an enormous thermal and mechanical stability. ${ }^{4,5}$ They have been widely used as matrixes for advanced composites or as resins in their own right for structural applications, especially for automotive, aerospace and $\mathrm{mi}-$ croelectronic utilities. ${ }^{6}$ Acetoguanamine (2,4-diamino-6-methyl-1,3,5-triazine) is one of the most widely used s-triazine derivatives, because it is a commercially available, inexpensive material and it has an excellent ability to undergoes nucleophilic substitution reaction under controlled temperature, ${ }^{7,8}$ which allow it to be useful in many material and pharmaceutical, ${ }^{9,10}$ and industrial applications. ${ }^{11-13}$

The design and synthesis of supramolecular polynuclear metal complexes have been an area of rapid growth for the past 20 years. ${ }^{14}$ During the last decade, a remarkable development in the preparation of self-assembled architecture through metal ion coordination has been observed. ${ }^{8}$ The motivation behind much of the studies related with polynuclear metal complexes has been provided by the prospect of producing a wide range of purpose-built materials with predetermined structures and potential applications in separation, gas storage, molecular recognition, and catalysis. ${ }^{8,14,15}$ The preparation of polymetallic complexes can be achieved using rationally designed polydentate ligands. ${ }^{16}$ On the other hand, it has been demonstrated that the 1,3,5-triazine ring is a suitable structural element to be incorporated into thermotropic liquid crystals. ${ }^{17}$ 
Schiff base chemistry, formed by the reversible condensation of amines and aldehydes has been made available in biomedicine as a result of its high efficiency and inoffensive by-product (only water). ${ }^{18-20}$ The Schiff-base cross-linked injectable hydrogels were reported to have tunable gelation kinetics, biodegradability, and self-repair functions. ${ }^{21-23}$

We now report the synthesis and characterization of polymeric Schiff base including two imin groups as new templates. The condensation reaction of acetoguanamine (2,4-diamino-6-methyl-1,3,5-triazine) with glutaraldehyde and terephthaldehyde in acetonitrile gave the desired polynuclear metal complexes moieties in a single step. ${ }^{24}$ The $\mathrm{NH}_{2}$ groups were then modified with dimeric acetoguanamine (2,4-diamino-6-methyl-1,3,5-triazine) as a single-directional linker, ${ }^{6-10}$ followed by treatment with $\mathrm{Co}(\mathrm{II}), \mathrm{Ni}(\mathrm{II})$ and $\mathrm{Cu}(\mathrm{II})^{11-20}$ to give the mentioned new cross linked polymeric Schiff bases metal complexes IV and $\mathrm{V}$.

\section{Experimental}

\section{1. Reagents and Solvents}

Both of solvents (acetonitrile and ethanol), acetoguanamine (1), glutaraldehyde, tereftaldehyde and $o$-phenylenediamine, acetic acid, $\mathrm{CoCl}_{2} \cdot 6 \mathrm{H}_{2} \mathrm{O}, \mathrm{NiCl}_{2}$. $6 \mathrm{H}_{2} \mathrm{O}, \mathrm{CuCl}_{2} \cdot 2 \mathrm{H}_{2} \mathrm{O}$ and sodium hydroxide were bought from Sigma and they were used without further purification. The ${ }^{1} \mathrm{H}$ NMR spectra of the polymers were taken with an Agilent NMR VNMRS spectrometer at $400 \mathrm{MHz}$, through their dimethyl sulfoxide (DMSO- $\mathrm{d}_{6}$ ) solutions. The internal standard of the NMR measurements was tetramethylsilane (TMS). FT-IR spectra were taken by Perkin Elmer 1600 Spectrum 100 ATR Polarization (4000$440 \mathrm{~cm}^{-1}$ ). Thermogravimetric Analysis (TGA) were performed using Hitachi STA7300 instrument. Elemental analyses were realized on a Leco 932 CHNS device where the results were in good harmony with the theoretical values. The metal contents of each complex were defined on a Varian, Vista AX CCD Simultaneous model ICP-AES. The $\mathrm{pH}$ values of all solutions were measured from a Milwaukee Mi $150 \mathrm{pH}$ meter. Magnetic moment values of the metal complexes were determined with a Sherwood Scientific MX Gouy magnetic susceptibility apparatus using the Gouy method with $\mathrm{Hg}\left[\mathrm{Co}(\mathrm{SCN})_{4}\right]$ as calibrant. The effective magnetic moments per metal atom, $\mu_{\text {eff }}$, were calculated using the well-known formula $\mu_{\text {eff }}=2.84 \sqrt{X_{M}} T$ B.M., where $\chi_{M}$ is the molar susceptibility.

\section{2. Synthesis of Polymeric Ligands}

\section{2. 1. Synthesis of IV}

Acetoguanamine $(0.125 \mathrm{~g}, 1.00 \mathrm{mmol})$ was solved in $25 \mathrm{~mL}$ acetonitrile under reflux for an hour. Equivalent amount of glutaraldehyde solution (\%2) was added to this solution drop by drop. Then, 5-6 drops of acetic acid were dropped as catalyst. This mixture was boiled under reflux for $3 \mathrm{hrs}$. The resulting precipitate was filtered off and dried under vacuum at $60^{\circ} \mathrm{C}$.

${ }^{1} \mathrm{H}$ NMR (ppm) data for IV: 7.50 (2H, triplet), 2.40 (3H, singlet), $2.20-2.05\left(6 \mathrm{H}\right.$, multiplet); FT-IR $\left(\mathrm{cm}^{-1}\right)$ data for $\mathbf{I V}=2926,2854\left(\mathrm{CH}_{\text {aliphatic }}\right), 1655(\mathrm{CH}=\mathrm{N}), 1537$ $\left(\mathrm{CH}=\mathrm{N}_{\text {triazine }}\right)$.

\section{2. 2. Synthesis of $V$}

Acetoguanamine $(0.125 \mathrm{~g}, 1.00 \mathrm{mmol})$ was solved in $25 \mathrm{~mL}$ acetonitrile under reflux for an hour. Then, teraftalaldehyde $(0,134 \mathrm{~g}, 1.00 \mathrm{mmol})$ was added to this solution portionwise. And then, $2 \mathrm{~mL}$ of acetic acid were dropped as catalyst. This mixture was boiled under reflux for $2 \mathrm{hrs}$. The resulting precipitate was filtered off and dried under vacuum at $60^{\circ} \mathrm{C}$.

${ }^{1} \mathrm{H}$ NMR (ppm) data for V: 8.80 (2H, singlet), 8.05$7.70\left(4 \mathrm{H}\right.$, multiplet), $2.40\left(3 \mathrm{H}\right.$, singlet); FT-IR $\left(\mathrm{cm}^{-1}\right)$ data for V: $1633(\mathrm{CH}=\mathrm{N}), 1556(\mathrm{CH}=\mathrm{N}$ triazine $)$.

\section{3. Synthesis of Cross-Linked Polymeric Complexes (VI-XI)}

IV or V ( $0.44 \mathrm{~g}$ or $0.51 \mathrm{~g}, 1.00 \mathrm{mmol})$ were solved in $50 \mathrm{~mL}$ of $0.1 \mathrm{M} \mathrm{HCl}$ solution. Then, equivalent amount of $0.001 \mathrm{M} \mathrm{CoCl}_{2} \cdot 6 \mathrm{H}_{2} \mathrm{O}, \mathrm{NiCl}_{2} \cdot 6 \mathrm{H}_{2} \mathrm{O}, \mathrm{CuCl}_{2} \cdot 2 \mathrm{H}_{2} \mathrm{O}$ in ethanol were added to these solutions drop by drop. These mixtures were heated under reflux at $60{ }^{\circ} \mathrm{C}$. Finally, the $\mathrm{pH}$ of the system was adjusted to around 6.00 with $\mathrm{NaOH} 5 \%$. The resulting precipitate (the $\mathrm{Co}(\mathrm{II}), \mathrm{Ni}(\mathrm{II}), \mathrm{Cu}(\mathrm{II})$ crosslinked polymeric complexes of AGGA and AGTA) were filtered off and dried under vacuum at $60^{\circ} \mathrm{C}$.

FT-IR $\left(\mathrm{cm}^{-1}\right)$ data for VI: 2926, $2854\left(\mathrm{CH}_{\text {alifatic }}\right)$, $1662(\mathrm{CH}=\mathrm{N}), 1545\left(\mathrm{CH}=\mathrm{N}_{\text {triazine }}\right), 540(\mathrm{Co}-\mathrm{N})$; FT-IR $\left(\mathrm{cm}^{-1}\right)$ data for VII: 2926, $2854\left(\mathrm{CH}_{\text {alifatic }}\right), 1662(\mathrm{CH}=\mathrm{N})$, $1545\left(\mathrm{CH}=\mathrm{N}_{\text {triazine }}\right), 541(\mathrm{Ni}-\mathrm{N})$; FT-IR $\left(\mathrm{cm}^{-1}\right)$ data for VIII: 2926, $2854\left(\mathrm{CH}_{\text {alifatic }}\right), 1662(\mathrm{CH}=\mathrm{N}), 1545(\mathrm{CH}=\mathrm{N}-$ triazine), $540(\mathrm{Cu}-\mathrm{N})$; FT-IR $\left(\mathrm{cm}^{-1}\right)$ data for IX: 1648 $(\mathrm{CH}=\mathrm{N}), 1568(\mathrm{CH}=\mathrm{N}$ triazine $), 545(\mathrm{Co}-\mathrm{N}) ; \mathrm{FT}-\mathrm{IR}\left(\mathrm{cm}^{-1}\right)$ data for X: $1648(\mathrm{CH}=\mathrm{N}), 1568(\mathrm{CH}=\mathrm{N}$ triazine $), 546(\mathrm{Ni}-$ $\mathrm{N})$; FT-IR $\left(\mathrm{cm}^{-1}\right)$ data for XI: $1648(\mathrm{CH}=\mathrm{N}), 1568(\mathrm{CH}=\mathrm{N}$ triazine), $545(\mathrm{Cu}-\mathrm{N})$.

\section{4. Determination of The Average Molecular Weight of IV and V by Measuring Intrinsic Viscosity}

In order to determine the average molecular weights of the IV and V polymers we synthesized here, we measured their solution viscosity using the Ostwald viscometer. The average molecular weight of polymeric ligands IV and $\mathbf{V}$ was then determined from the Mark Houwink's relation $\left([\eta]=K M^{\alpha}\right.$, where $M$ is the molecular weight and $[\eta]$ is the intrinsic viscosity). The value of $[\eta]$ was deter- 
mined by using the Huggins relationship $\mathrm{n}_{\mathrm{sp}}=[\mathrm{n}] c+$ $\mathrm{k}^{\prime}[\mathrm{n}]^{2} c^{2}+\left(\right.$ or $\left.\mathrm{y}_{\mathrm{sp}} / c=[\mathrm{n}]+\mathrm{k}^{\prime}[\mathrm{n}]^{2} c\right)$, where $c$ is the concentration, $\mathrm{n}_{\mathrm{sp}}$ is the specific viscosity $\mathrm{n}_{\mathrm{sp}}\left(=\mathrm{n}_{\mathrm{rel}}-1=\left(\mathrm{n}-\mathrm{n}_{0}\right)\right.$ / $\left.\mathrm{n}_{0}\right)$, and $\mathrm{n}_{\text {rel }}\left(=\mathrm{n} / \mathrm{n}_{0}=t / t_{0}\right)$ is the relative viscosity that was obtained from the measured viscosities of solvent $\left(\mathrm{n}_{0}\right)$ and polymer solution ( $\mathrm{n})$; $t$ and $t_{0}$ are flow times of the solution and the solvent. The specific viscosity is affected by the solution concentration and its dependence on $c$ is given by the Huggins relation. The intrinsic viscosity $[\eta]$ is determined by extrapolation of $\eta_{\mathrm{sp}} / c$ to $c=0$. According to this, dilute solutions of IV and $\mathrm{V}$ were prepared at different concentrations in toluene at $30^{\circ} \mathrm{C}$. Intrinsic viscosity values obtained are $[\eta]=1.494 \mathrm{~kg} \mathrm{~s} \mathrm{~m}^{-1}$ (for IV), $\mathrm{n}=1.985 \mathrm{~kg}$ $\mathrm{s} \mathrm{m}^{-1}$ (for $\mathbf{V}$ ).<smiles>CC(C)=Nc1nc(C)nc(/N=C/c2ccc(C)cc2)n1</smiles>

(V)

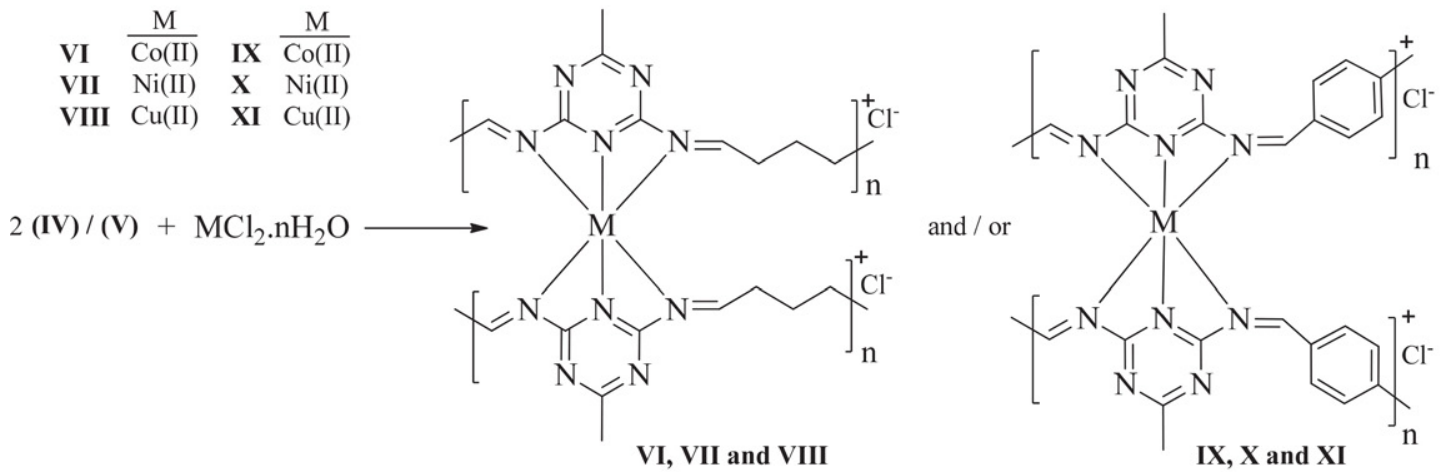

Scheme 1: The synthetic route of polymeric ligands and their cross linked polymeric complexes.

Table 1. The elemental analysis data and physical properties of all ligands and complexes.

\begin{tabular}{|c|c|c|c|c|c|c|c|c|c|}
\hline \multirow[t]{2}{*}{$\begin{array}{l}\text { [Empirical Formula] } \\
\text { (Compound Codes) }\end{array}$} & \multirow{2}{*}{$\begin{array}{c}\mu \text { eff } \\
\text { (B.M.) } \\
296 \text { K }\end{array}$} & \multirow[t]{2}{*}{ M.P ${ }^{\circ} \mathrm{C}$} & \multirow[t]{2}{*}{ Color } & \multirow[t]{2}{*}[\mathrm{Mw}]{} & \multirow[t]{2}{*}{ Yield \% } & \multicolumn{3}{|c|}{$\begin{array}{c}\text { Contents (\%) } \\
\text { Calculated/Found }\end{array}$} & \multirow[b]{2}{*}{$\mathbf{M}^{\star *}$} \\
\hline & & & & & & C & $\mathbf{H}$ & $\mathbf{N}$ & \\
\hline $\mathrm{C}_{9} \mathrm{H}_{11} \mathrm{~N}_{5}$ (IV) & Dia & 106 & White & {$[189]_{\mathrm{n}}$} & 68 & $\begin{array}{l}57.14 \\
56.70\end{array}$ & $\begin{array}{l}5.82 \\
5.75\end{array}$ & $\begin{array}{l}37.04 \\
36.91\end{array}$ & - \\
\hline $\mathrm{C}_{12} \mathrm{H}_{9} \mathrm{~N}_{5}(\mathrm{~V})$ & Dia & 108 & Yellow & {$[223]_{\mathrm{n}}$} & 65 & $\begin{array}{l}64.57 \\
64.15\end{array}$ & $\begin{array}{l}4.04 \\
3.85\end{array}$ & $\begin{array}{l}31.39 \\
29.13\end{array}$ & - \\
\hline $\mathrm{C}_{18} \mathrm{H}_{22} \mathrm{~N}_{10} \mathrm{CoCl}_{2}(\mathrm{VI})$ & 3.76 & $>400^{*}$ & Orange & {$[507.93]_{\mathrm{n}}$} & 58 & $\begin{array}{l}42.53 \\
41.78\end{array}$ & $\begin{array}{l}4.31 \\
3.85\end{array}$ & $\begin{array}{l}27.56 \\
\mathbf{2 6 . 8 2}\end{array}$ & $\begin{array}{l}11.60 \\
\mathbf{1 0 . 9 8}\end{array}$ \\
\hline $\mathrm{C}_{18} \mathrm{H}_{22} \mathrm{~N}_{10} \mathrm{NiCl}_{2}$ (VII) & 2.81 & $>400^{\star}$ & Brown & {$[507.69]_{\mathrm{n}}$} & 60 & $\begin{array}{l}42.55 \\
41.90\end{array}$ & $\begin{array}{l}4.33 \\
3.98\end{array}$ & $\begin{array}{l}27.56 \\
\mathbf{2 7 . 1 8}\end{array}$ & $\begin{array}{l}11.56 \\
11.17\end{array}$ \\
\hline $\mathrm{C}_{18} \mathrm{H}_{22} \mathrm{~N}_{10} \mathrm{CuCl}_{2}$ (VIII) & 1.76 & $>400^{*}$ & Claret Red & {$[512.55]_{\mathrm{n}}$} & 55 & $\begin{array}{l}42.14 \\
41.78\end{array}$ & $\begin{array}{l}4.29 \\
3.82\end{array}$ & $\begin{array}{l}27.31 \\
\mathbf{2 7 . 0 6}\end{array}$ & $\begin{array}{l}12.40 \\
12.02\end{array}$ \\
\hline $\mathrm{C}_{24} \mathrm{H}_{18} \mathrm{~N}_{10} \mathrm{CoCl}_{2}$ (IX) & 3.75 & $>400^{*}$ & Violet & {$[575.93]_{\mathrm{n}}$} & 62 & $\begin{array}{l}50.01 \\
49.73\end{array}$ & $\begin{array}{l}3.13 \\
2.97\end{array}$ & $\begin{array}{l}24.31 \\
\mathbf{2 4 . 1 1}\end{array}$ & $\begin{array}{l}10.23 \\
10.01\end{array}$ \\
\hline $\mathrm{C}_{24} \mathrm{H}_{18} \mathrm{~N}_{10} \mathrm{NiCl}_{2}(\mathrm{X})$ & 2.79 & $>400^{*}$ & Dark Green & {$[575.69]_{\mathrm{n}}$} & 65 & $\begin{array}{l}50.02 \\
49.55\end{array}$ & $\begin{array}{l}3.13 \\
3.12\end{array}$ & $\begin{array}{l}24.32 \\
23.77\end{array}$ & $\begin{array}{l}10.19 \\
09.38\end{array}$ \\
\hline $\mathrm{C}_{24} \mathrm{H}_{18} \mathrm{~N}_{10} \mathrm{CuCl}_{2}$ (XI) & 1.75 & $>400^{*}$ & Light Green & {$[580.55]_{\mathrm{n}}$} & 67 & $\begin{array}{l}49.61 \\
49.08\end{array}$ & $\begin{array}{l}3.10 \\
3.04\end{array}$ & $\begin{array}{l}24.12 \\
\mathbf{2 4 . 0 1}\end{array}$ & $\begin{array}{l}10.95 \\
\mathbf{1 0 . 1 6}\end{array}$ \\
\hline
\end{tabular}

${ }^{\star}$ Decomposition point, ${ }^{* *} \mathrm{M}=\mathrm{Co}(\mathrm{II}), \mathrm{Ni}(\mathrm{II})$ ve $\mathrm{Cu}(\mathrm{II}), \mu_{\text {eff }}=$ Effective magnetic moment 


\section{Results and Discussions}

In this study, 2,4-diamino-6-methyl-1,3,5-triazine (acetoguanamine) was used as the starting material. 2,4-diamino-6-methyl-1,3,5-triazine was boiled under reflux with glutaraldehyde and terephthaldehyde in acetonitrile using acetic acid as catalyst. And, s-triazine-containing polymer ligands codded as IV and V were obtained by these condensation reactions. These target s-triazin containing polymer ligands obtained were analyzed by ${ }^{1} \mathrm{H}$ NMR, FT-IR, TGA and elemental analysis. Then, polymeric metal $\left(\mathrm{Co}^{2+}, \mathrm{Ni}^{2+}\right.$ and $\left.\mathrm{Cu}^{2+}\right)$ complexes of the polymeric ligands codded as (VI-XI) were obtained from the interaction with $\mathrm{CoCl}_{2} \cdot 6 \mathrm{H}_{2} \mathrm{O}, \mathrm{NiCl}_{2} \cdot 6 \mathrm{H}_{2} \mathrm{O}$ and $\mathrm{Cu}-$ $\mathrm{Cl}_{2} \cdot 2 \mathrm{H}_{2} \mathrm{O}$ at $60{ }^{\circ} \mathrm{C}$ in ethyl alcohol. The structures of these complexes were also illuminated and elucidated using FTIR, elemental analysis, thermogravimetric analysis and magnetic susceptibility analysis. The polymerization degrees of the polymeric ligands were determined by the molecular weight determination study with the viscometer.
Based on the elemental analysis, spectral studies and the coordination geometry has been assigned and is shown in Scheme 1 and Table 1.

\section{1. Interpretation of ${ }^{1} \mathrm{H}$ NMR Spectra}

In the ${ }^{1} \mathrm{H}$-NMR spectrum of the resulting s-triazine-containing polymer IV, the triplet for two protons at $7.50 \mathrm{ppm}$, the singlet for three protons at $2.40 \mathrm{ppm}$ and the multiplet for six protons in the range of $2.20-2.05 \mathrm{ppm}$ were observed and attributed to $\mathrm{CH}=\mathrm{N}$ group, $\mathrm{CH}_{3}$ group on triazine and aliphatic $\mathrm{CH} / \mathrm{CH}_{2}$ groups, respectively. As for the polymer $\mathrm{V}$, the singlet for two protons at $8.80 \mathrm{ppm}$, the multiplet for four protons in the range of 8.05-7.70 $\mathrm{ppm}$ and the singlet for three protons at $2.40 \mathrm{ppm}$ were observed and attributed to $\mathrm{CH}=\mathrm{N}$ group, aromatic $\mathrm{CH}$ and $\mathrm{CH}_{3}$ group on triazine, respectively. These peaks observed in the ${ }^{1} \mathrm{H}$ NMR spectra proved that both structures were successfully obtained. ${ }^{25-28}$

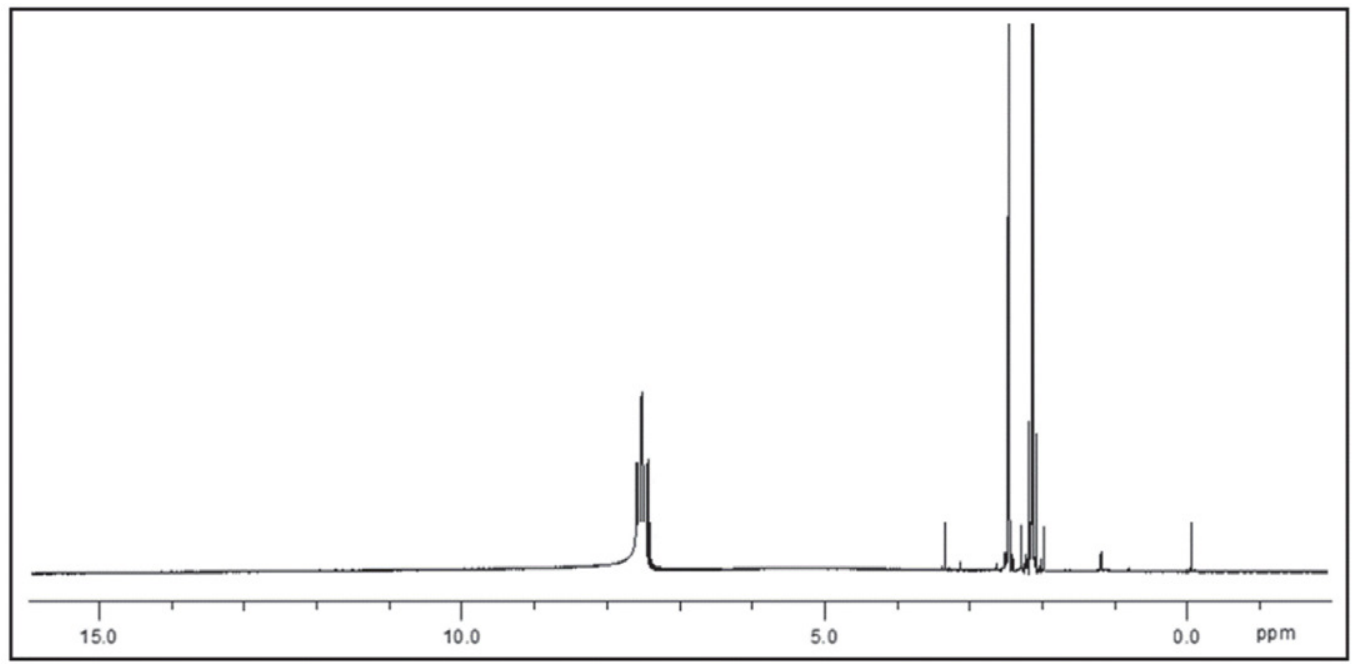

Figure 1. ${ }^{1} \mathrm{H}$ NMR spectrum of IV.

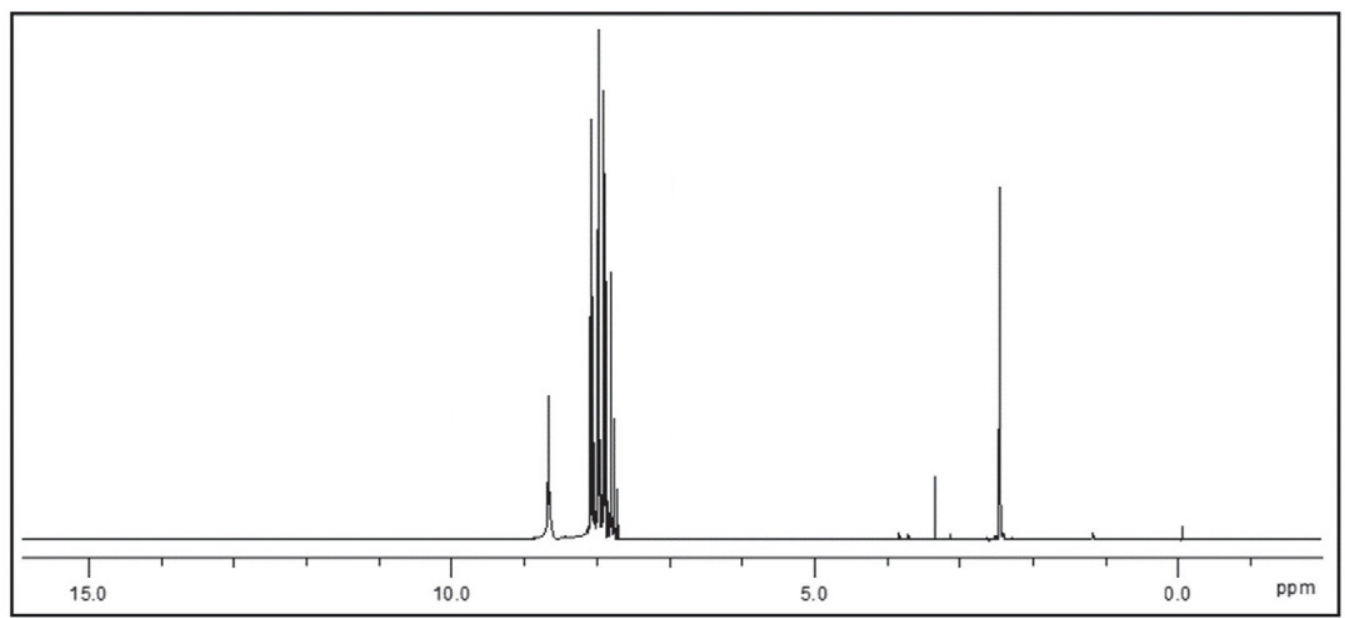

Figure 2. ${ }^{1} \mathrm{H}$ NMR spectrum of $\mathbf{V}$. 


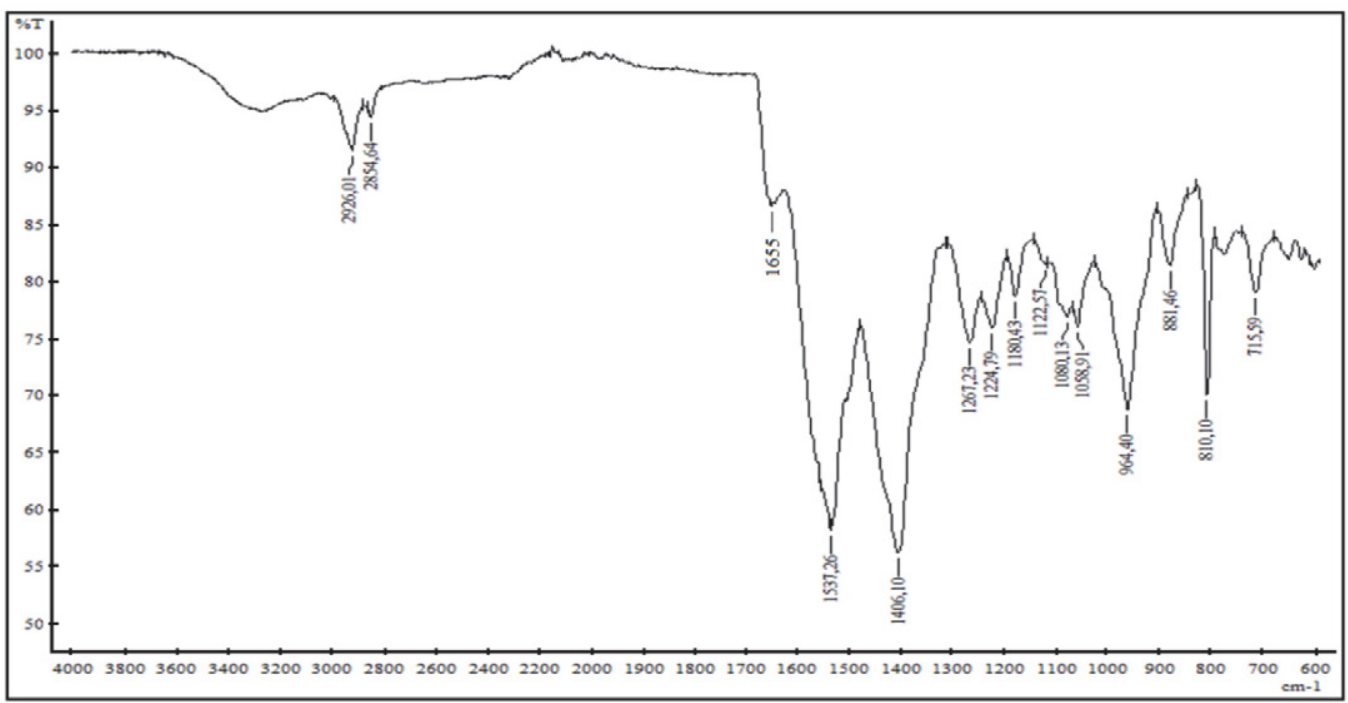

Figure 3: FT-IR spectrum of IV.

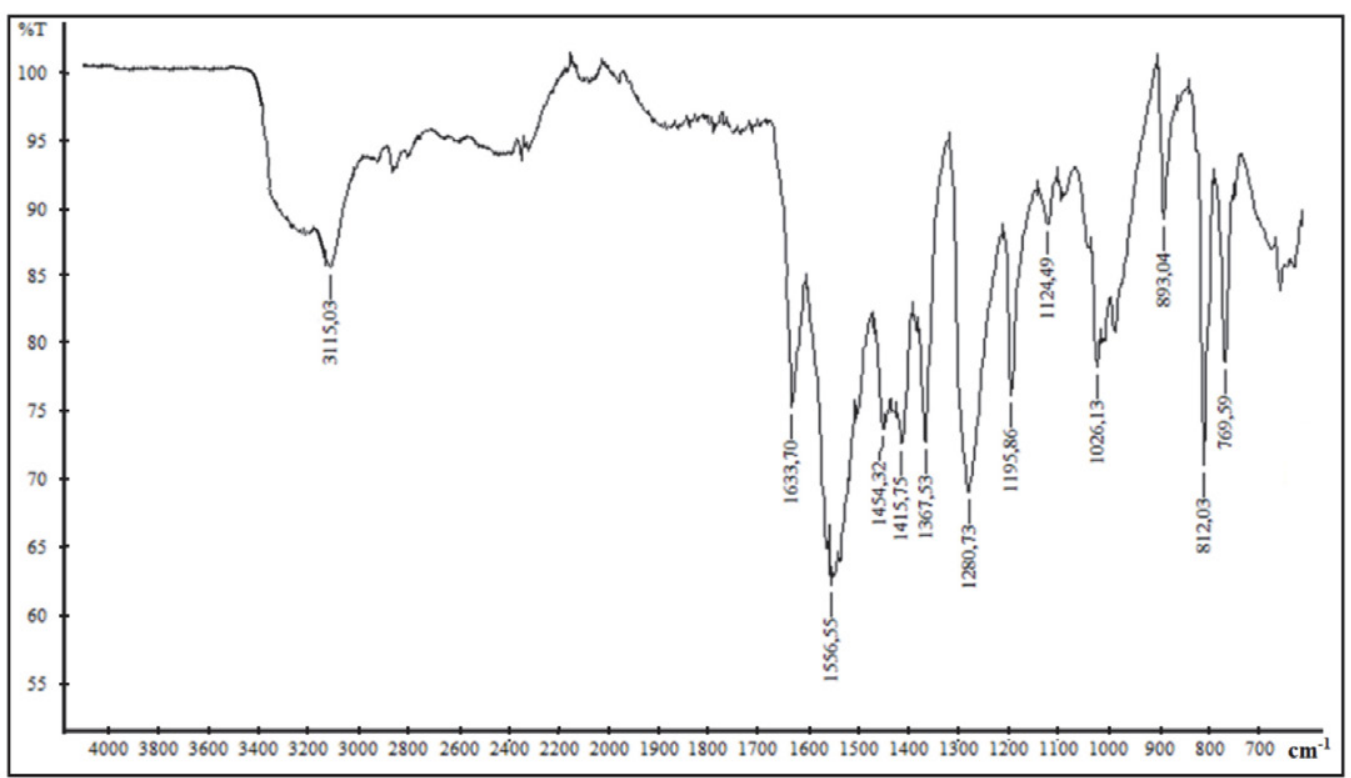

Figure 4: FT-IR spectrum of V.

\section{2. Interpretation of FT-IR Spectra}

The FT-IR spectra of the polymer ligands and their complexes we synthesized were recorded and the bands we observed were summarized in the experimental section. Firstly, when we look at the FT-IR spectra of the polymer ligands we synthesized, $\mathrm{C}=\mathrm{N}$ bands from the central s-triazine groups were observed at $1537 \mathrm{~cm}^{-1}$ and $1556 \mathrm{~cm}^{-1}$ for IV and V, respectively. Disappearance of $\mathrm{N}-\mathrm{H}$ bending band at $3391 \mathrm{~cm}^{-1}$ and N-H bending band at $1510 \mathrm{~cm}^{-1}$ for acetoguanamine and instead, appearance of $\mathrm{C}=\mathrm{N}$ stretching bands at $1655 \mathrm{~cm}^{-1}$ and $1633 \mathrm{~cm}^{-1}$ for IV and V, respectively, aliphatic C-H stretching bands at $2926 \mathrm{~cm}^{-1}$ and $2854 \mathrm{~cm}^{-1}$ for IV proves that glutaraldehyde and tereftalaldehyde linked to the s-triazine ring of acetoguanamine. ${ }^{5,29,30}$
Schiff base polymeric complexes were obtained from the reaction of polymer Schiff base ligands (IV and V) with metal salts of $\mathrm{CoCl}_{2} \cdot 6 \mathrm{H}_{2} \mathrm{O}, \mathrm{NiCl}_{2} \cdot 6 \mathrm{H}_{2} \mathrm{O}$ and $\mathrm{CuCl}_{2} \cdot 2 \mathrm{H}_{2} \mathrm{O}$ under reflux in ethanol. In order to study the binding mode of the ligand to the metal in complexes, the FT-IR spectrum of the free ligand was compared with the spectra of the metal(II) complexes. In the FT-IR spectra of the obtained complexes, bands of $\mathrm{C}=\mathrm{N}$ Schiff base and s-triazine $\mathrm{C}=\mathrm{N}$ groups were observed to shift to 12-15 $\mathrm{cm}^{-1}$ higher wave number after complex formation. The FT-IR spectra of the ligands show strong bands at $1537 \mathrm{~cm}^{-1}$ and $1556 \mathrm{~cm}^{-1}$ for IV and $\mathbf{V}$, respectively assigned to $\mathrm{C}=\mathrm{N}$ group of s-triazine. These bands are shifted to higher wave number in the spectra of all the complexes indicate the coordination of triazine ring nitrogen to the metal. In addition, $\mathrm{M}-\mathrm{N}$ stretching bands 


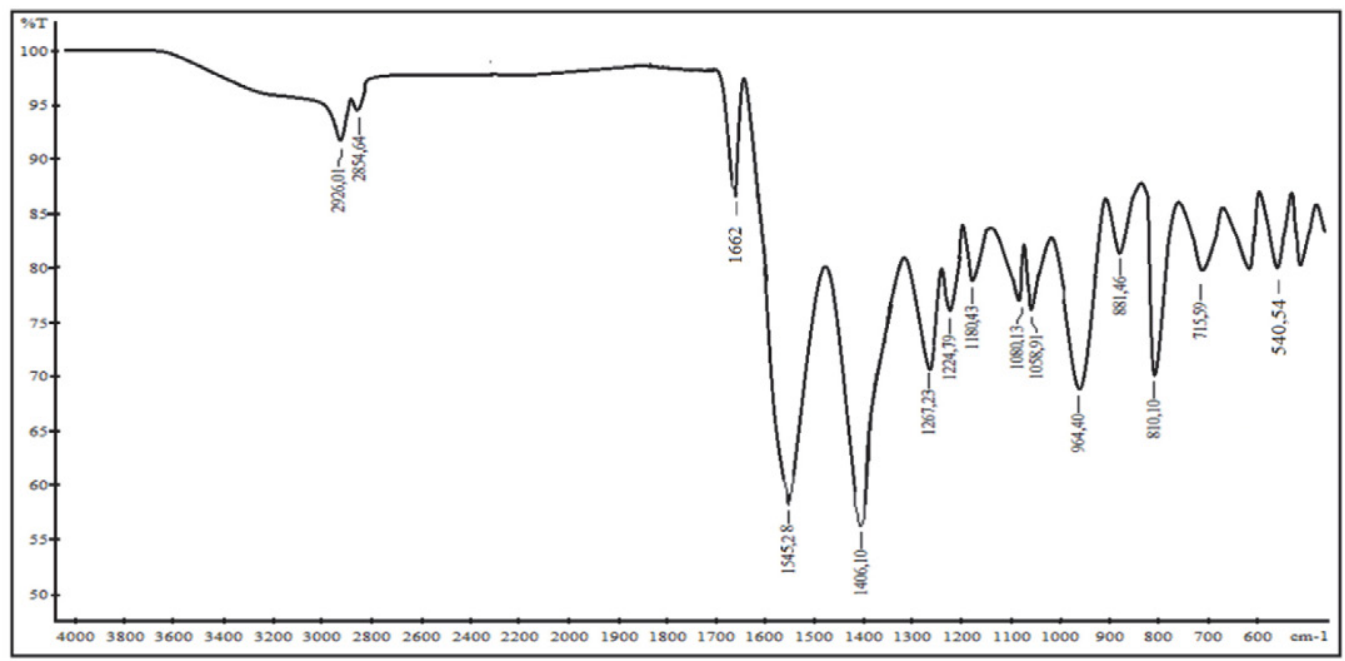

Figure 5. FT-IR spectrum of Co(II) cross polymer complex of IV.

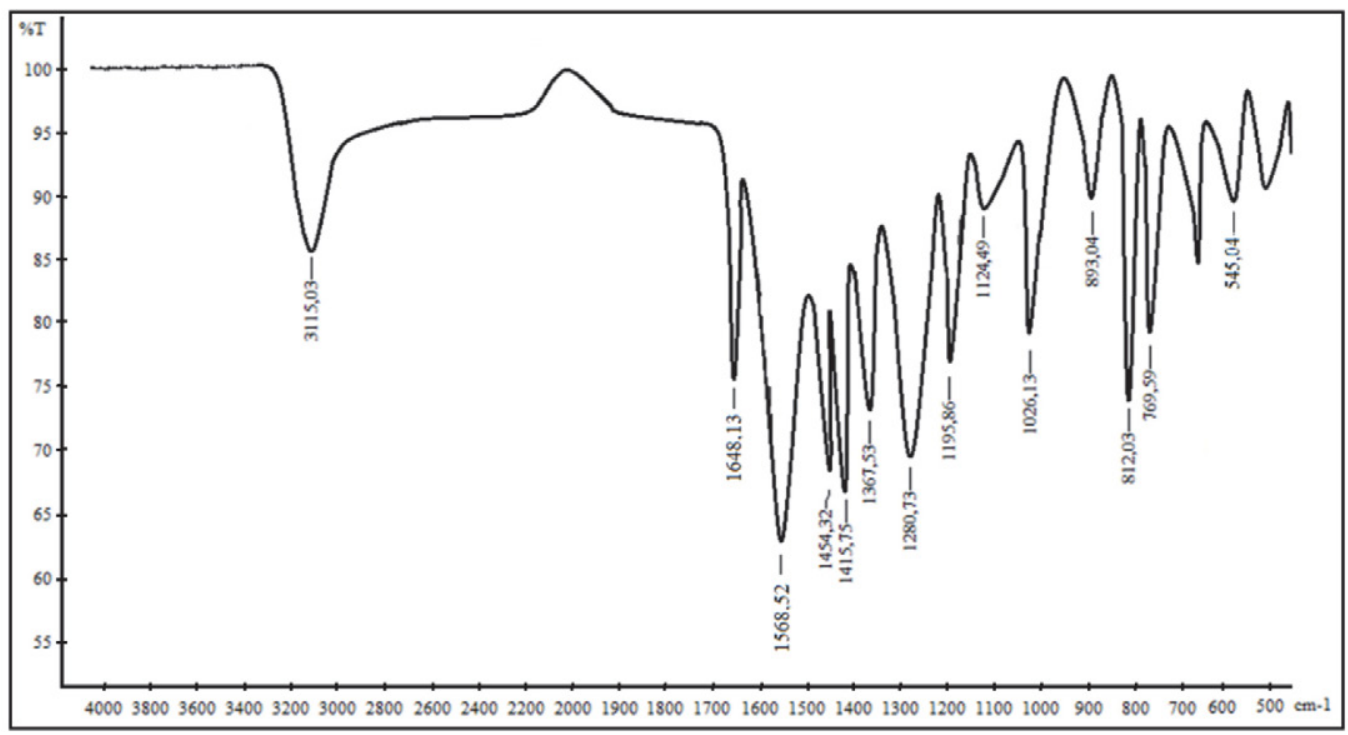

Figure 6: FT-IR spectrum of Co(II) cross polymer complex of V.

were observed at $540 \mathrm{~cm}^{-1}$ and $545 \mathrm{~cm}^{-1}$, respectively. $5,28,29,31-34$

\section{3. Interpretation of Magnetic Data}

In order to obtain information about the magnetic characters and geometries of s-triazine-containing polymeric complexes, effective magnetic moment $\left(\mu_{\text {eff }}\right)$ values were measured at $25{ }^{\circ} \mathrm{C}$. $\mu_{\text {eff }}$ values of all complexes are given in Table 1. All polymeric complexes were determined as paramagnetic with $\mathrm{d}^{7}, \mathrm{~d}^{7}, \mathrm{~d}^{8}, \mathrm{~d}^{8}, \mathrm{~d}^{9}$ and $\mathrm{d}^{9}$ metal ions electron arrangement for VI-XI, respectively. Their effective magnetic moment $\left(\mu_{\text {eff }}\right)$ values were determined as follows: $3.76,3.75,2.81,2.79,1.76$ and 1.75 B.M for each $\mathrm{Co}(\mathrm{II}), \mathrm{Ni}(\mathrm{II})$ and $\mathrm{Cu}(\mathrm{II})$ ions in $\left[\left(\mathrm{b}_{2 \mathrm{~g}}\right)^{2}\left(\mathrm{e}_{\mathrm{g}}\right)^{3}\left(\mathrm{~b}_{1 \mathrm{~g}}\right)^{1}\left(\mathrm{a}_{1 \mathrm{~g}}\right)^{1}\right]$, $\left[\left(b_{2 g}\right)^{2}\left(e_{g}\right)^{4}\left(b_{1 g}\right)^{1}\left(a_{1 g}\right)^{1}\right]$ and $\left[\left(b_{2 g}\right)^{2}\left(e_{g}\right)^{4}\left(b_{1 g}\right)^{2}\left(a_{1 g}\right)^{1}\right]$ electronic arrangement, respectively. The magnetic moments of the complexes are lower than the theoretical spin-only values for three, two and one unpaired electrons, respectively. According to our results, it was concluded that these complexes have distorted octahedral geometry (flat tetragonal distortion). ${ }^{5,32,35-39}$ These results also support the proposed geometry. In other words, the fact that the s-triazine ring acts as a three-dentate ligand has forced geometry into distorted (flat tetragonal distortion) octahedral geometry. There are some examples in the literature supporting this geometry. ${ }^{40,41}$

\section{4. Interpretation of Thermal Analyses Curves}

In order to determine the thermal behavior of the ligands and complexes we obtained, the ligands and complexes were heated in a nitrogen atmosphere at a temper- 


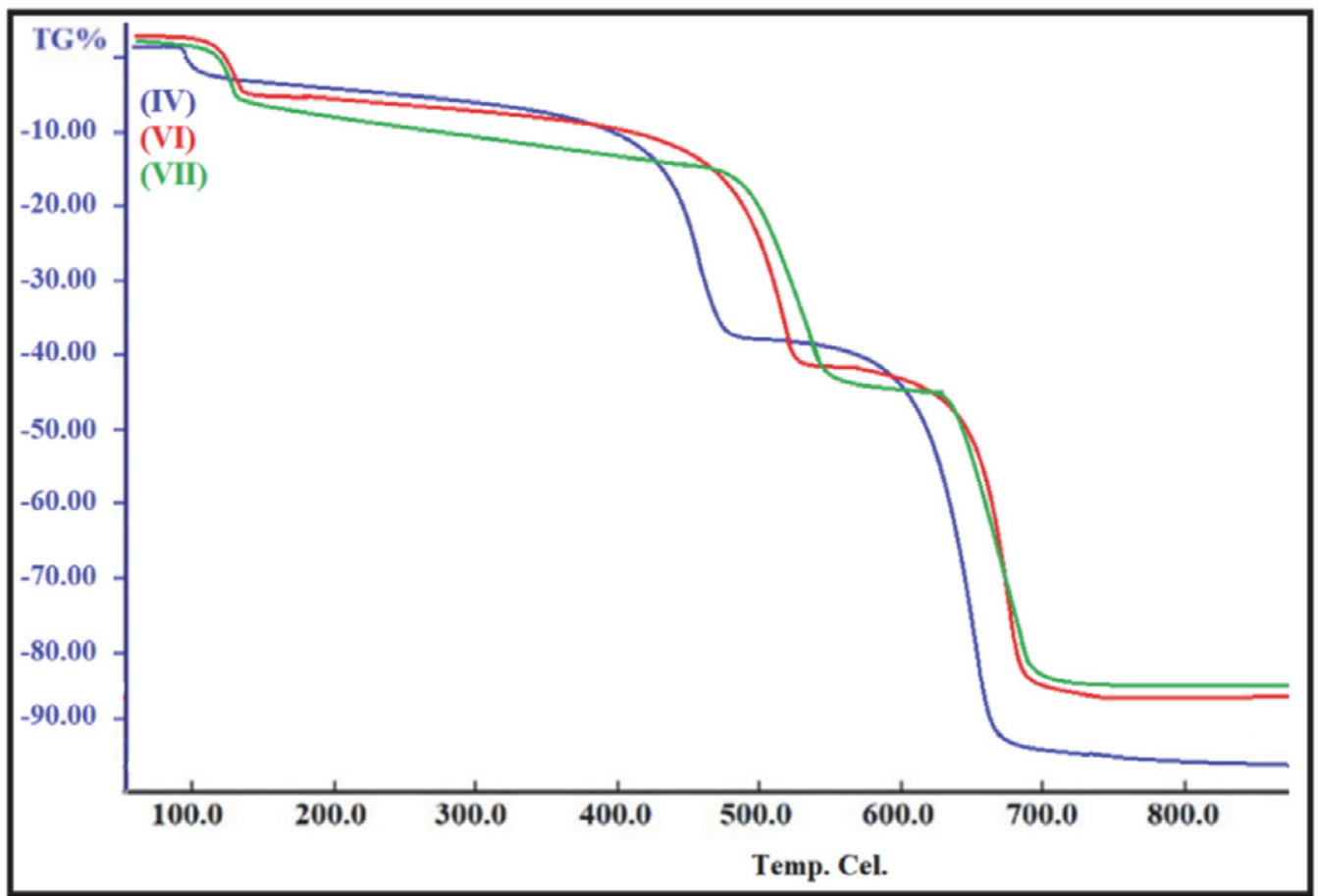

Figure 7. TGA curves of IV, VI and VII

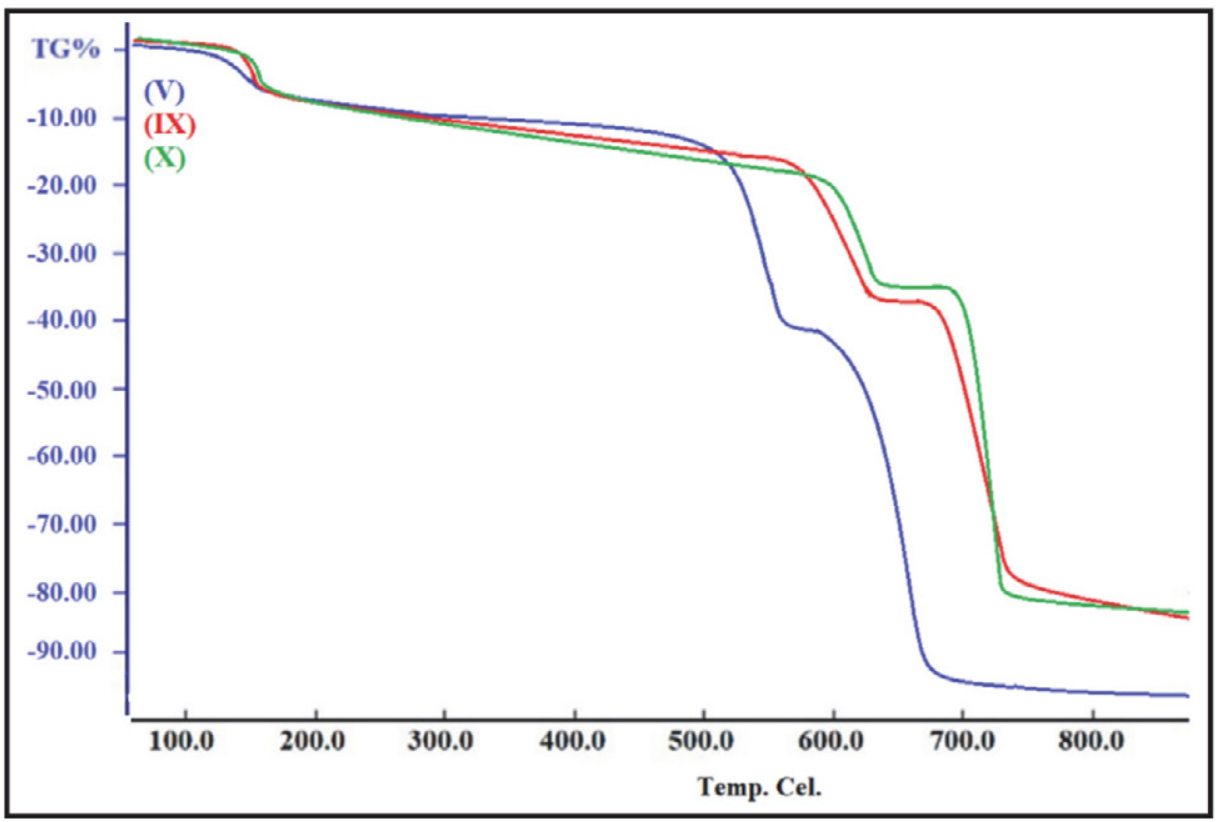

Figure 8. TGA curves of $\mathbf{V}, \mathbf{I X}$ and $\mathbf{X}$

ature of $50-1000{ }^{\circ} \mathrm{C}$ at a rate of $10{ }^{\circ} \mathrm{C} / \mathrm{min}$. When we interpret the TGA graphs obtained as a result of thermal analysis, we observed that the ligands and complexes decompose in two steps. However, we observed that the ligand $\mathbf{V}$ begins to decompose at a temperature of about 65 ${ }^{\circ} \mathrm{C}$ higher than the ligand IV that the main skeleton is degraded immediately after both ligands begin to decompose. The experimentally observed mass loss corresponds approximately to the mass of glutaraldehyde for the ligand
IV and tereftaldehyde for the ligand V. After 5.5\% moisture loss of the ligand $\mathbf{I V}$ in the temperature range of 90 $105^{\circ} \mathrm{C}$, the weight loss in the first step began at $480^{\circ} \mathrm{C}$ and was completed at $485{ }^{\circ} \mathrm{C}$. The weight loss in this step is about $33 \%$. After $4.5 \%$ moisture loss of the ligand $\mathbf{V}$ in the temperature range of $90-105{ }^{\circ} \mathrm{C}$, the weight loss in the first step began at $545{ }^{\circ} \mathrm{C}$ and was completed at $550{ }^{\circ} \mathrm{C}$. The weight loss in this step is about $40 \%$. It was calculated that the weight losses in the last steps observed around 
$650{ }^{\circ} \mathrm{C}$ were equal to the mass of the remaining s-triazine ring. ${ }^{5,42}$

When we examined the TGA curves of the Co(II), $\mathrm{Ni}(\mathrm{II})$ and $\mathrm{Cu}(\mathrm{II})$ complexes of these ligands, we observed that the decomposition temperature shifted to about $40{ }^{\circ} \mathrm{C}$ higher. When we look at the rate of decomposition, we observed that there is not much difference compared to ligands. That is, while these polymeric complexes using metal ions as crosslinkers decompose, the 5-membered aliphatic chain from glutaraldehyde, and the aromatic ring from terephthaldehyde, which are the polymerizing groups, appear to decompose, firstly. It was calculated that the weight losses in the last steps observed in the temperature range of $680-720^{\circ} \mathrm{C}$ were equal to the mass of the remaining s-triazine ring. The metal halide salts remain in the complexes without decomposition. ${ }^{5,42}$

\section{5. Interpretation of Average Molecular Weight of Polymer Ligands}

The average molecular weights of the polymers IV and $\mathbf{V}$ were determined from the measured intrinsic viscosities: $\eta=1.494 \mathrm{~kg} \mathrm{~s} \mathrm{~m}^{-1}$ (for IV), $\eta=1.985 \mathrm{~kg} \mathrm{~s} \mathrm{~m}^{-1}$ (for $\mathrm{V}$ ). Using the equation $\eta=K M \alpha$ (with polystyrene as standard, ${ }^{5} K=1.7 \times 10^{-4}$ and $\alpha=0.78$ ), the average molecular weights of these polymers are $9800 \mathrm{~g} / \mathrm{mol}$ (IV) and $14200 \mathrm{~g} / \mathrm{mol}(\mathrm{V})$. Using these data, it is concluded that these polymers consist of an average of 48 and 56 monomer units, respectively. ${ }^{5,43,44}$ Because of the usage of polystyrene as standard, the actual molecular weight values might be slightly higher than observed. The reason of the detected values to be lower is the fact that the polymers have a spherical type structure, also supported by other studies. $^{5}$

\section{Conclusion}

In this work, we synthesized two novel s-triazine-cored Schiff base polymeric ligands including acetoguanamine group and their six-novel cross-linked polynuclear complexes. These complexes are the first examples of these s-triazine-cored Schiff base polymeric complexes coordinated by imine groups to the $\mathrm{Co}(\mathrm{II}), \mathrm{Ni}(\mathrm{II})$ or $\mathrm{Cu}(\mathrm{II})$ centers. The magnetic data for the complexes show good harmony with the $\mathrm{d}^{7}(\mathrm{~S}=3 / 2)$ (for $\mathrm{Co}(\mathrm{II})$ complexes), the $\mathrm{d}^{8}(\mathrm{~S}=1)$ (for $\mathrm{Ni}(\mathrm{II})$ complexes) and $\mathrm{d}^{9}(\mathrm{~S}=1 / 2)$ (for both $\mathrm{Cu}$ (II) complexes) metal ion in distorted octahedral geometry (flat tetragonal distortion). When we interpret the TGA graphs obtained as a result of thermal analysis, we observed that the ligands and complexes decompose in two steps. It has been observed that these polymeric complexes are thermally stable complexes until $480{ }^{\circ} \mathrm{C}$. According to the results of viscosity measurement, it can be concluded that polymeric ligands (IV and $\mathbf{V}$ ) have average 48 and 56 monomer units, respectively.

\section{Conflict of Interest}

The authors declare that there is no conflict of interest related to this work.

\section{Acknowledgement}

We acknowledge that this study was financially supported by the Karabuk University Scientific Research Projects Coordinatorship (Project No: KBÜBAP-17-YL-036).

\section{References}

1. S. M. Osman, S. N. Khattab, E. A. Aly, E. Kenawy, A. El-Faham, J. Polym. Res. 2017, 24, 231-244.

DOI:10.1007/s10965-017-1385-2

2. Z. E. Koc, H. Bingol, A. O. Saf, E. Torlak, A. Coskun, J. Hazard. Mater. 2010, 183, 251-255.

3. G. Blotny, Tetrahedron 2006, 62, 9507-9522. DOI:10.1016/j.tet.2006.07.039

4. S. Uysal, Z. E. Koc, S. Celikbilek, H. I. Ucan, Synthetic Commun. 2012, 42, 1033-1044.

DOI:10.1080/00397911.2010.535635

5. S. Uysal, J. Incl. Phenom. Macro. 2013, 76, 223-230. DOI:10.1007/s10847-012-0194-9

6. G. P. Yu, C. Liu, J. Y. Wang, X. P. Li, X. G. Jian, Polym. Degrad. Stabil. 2010, 95, 2445-2452.

DOI:10.1016/j.polymdegradstab.2010.08.011

7. A. El-Faham, S. M. Soliman, H. A. Ghabbour, Y. A. Elnakady, T. A. Mohaya, M. R. H. Siddiqui, F. Albericio, J. Mol. Struct. 2016, 1125, 121-135.

DOI:10.1016/j.molstruc.2016.06.061

8. Z. E. Koc, J. Heterocyclic Chem. 2011, 48, 769-775. DOI:10.1002/jhet.577

9. M. Xie, W. Wei, Z. F. Jiang, Y. G. Xu, J. M. Xie, Ceram. Int. 2016, 42, 4158-4170. DOI:10.1016/j.ceramint.2015.11.089

10. H. S. Patel, S. N. Desai, J. Polym. Mater. 2008, 25, 519-527.

11. J. W. Grate, K. F. Mo, M. D. Daily, Angew. Chem. Int. Ed. 2016, 55, 3925-3930. DOI:10.1002/anie.201509864

12. C. A. Figg, T. Kubo, B. S. Sumerlin, ACS Macro Lett. 2015, 4, 1114-1118. DOI:10.1021/acsmacrolett.5b00634

13. J. F. Zhou, J. J. Wang, K. K. Jin, J. Sun, Q. Fang, Polymer 2016, 102, 301-307. DOI:10.1016/j.polymer.2016.09.027

14. P. Gamez, P. de Hoog, M. Lutz, A. L. Spek, J. Reedijk, Inorg. Chim. Acta 2003, 351, 319-325.

DOI:10.1016/S0020-1693(03)00203-2

15. P. Gamez, P. de Hoog, M. Lutz, W. L. Driessen, A. L. Spek, J. Reedijk, Polyhedron 2003, 22, 205-210. DOI:10.1016/S0277-5387(02)01326-8

16. P. de Hoog, P. Gamez, W. L. Driessen, J. Reedijk, Tetrahedron Lett. 2002, 43, 6783-6786.

DOI:10.1016/S0040-4039(02)01498-3

17. D. Goldmann, D. Janietz, C. Schmidt, J. H. Wendorff, Liq. Cryst. 1998, 25, 711-719.

DOI:10.1080/026782998205723 
18. M. E. Belowich, J. F. Stoddart, Chem. Soc. Rev. 2012, 41, 2003-2024. DOI:10.1039/c2cs15305j

19. C. D. Meyer, C. S. Joiner, J. F. Stoddart, Chem. Soc. Rev. 2007, 36, 1705-1723. DOI:10.1039/b513441m

20. Y. Xin, J. Y. Yuan, Polym. Chem. 2012, 3, 3045-3055. DOI:10.1039/c2py20290e

21. G. H. Deng, C. M. Tang, F. Y. Li, H. F. Jiang, Y. M. Chen, Macromolecules 2010, 43, 1191-1194.

DOI:10.1021/ma9022197

22. F. Y. Liu, F. Y. Li, G. H. Deng, Y. M. Chen, B. Q. Zhang, J. Zhang, C. Y. Liu, Macromolecules 2012, 45, 1636-1645. DOI:10.1021/ma202461e

23. X. L. Wu, C. L. He, Y. D. Wu, X. S. Chen, Biomaterials 2016 , 75, 148-162. DOI:10.1016/j.biomaterials.2015.10.016

24. S. Uysal, Z. E. Koc, J. Mol. Struct. 2016, 1109, 119-126. DOI:10.1016/j.molstruc.2015.12.080

25. Z. E. Koc, H. I. Ucan, Transit. Metal. Chem. 2007, 32, 597602.

26. Z. E. Koc, S. Uysal, Helv. Chim. Acta 2010, 93, 910-919. DOI:10.1002/hlca.200900294

27. S. Uysal, Z. E. Koc, J. Hazard. Mater. 2010, 175, 532-539. DOI:10.1016/j.jhazmat.2009.10.038

28. B. Therrien, J. Organomet. Chem. 2011, 696, 637-651. DOI: $10.3109 / 9781841848372-20$

29. S. Uysal, H. I. Ucan, J. Incl. Phenom. Macro. 2010, 68, 165173. DOI: $10.1007 / \mathrm{s} 10847-010-9762-\mathrm{Z}$

30. I. T. Ahmed, A. A. A. Boraei, Spectrosc. Lett. 2005, 38, 4759. DOI:10.1081/SL-200045464

31. R. Shanmugakala, P. Tharmaraj, C. D. Sheela, J. Mol. Struct. 2014, 1076, 606-613.

DOI:10.1016/j.molstruc.2014.08.012

32. D. J. Reid, J. E. W. Cull, K. D. S. Chisholm, A. Langlois, P. H. Lin, J. Long, O. Lebel, I. Korobkov, R. Y. Wang, J. D. Wuest, M. Murugesu, J. Scott, Dalton Trans. 2011, 40, 5009-5017. DOI:10.1039/c1dt00018g
33. M. Shao, M. X. Li, Z. X. Wang, X. He, H. H. Zhang, Cryst. Growth Des. 2017, 17, 6281-6290.

DOI:10.1021/acs.cgd.7b00967

34. Q. L. Zhu, C. B. Tian, C. J. Shen, T. L. Sheng, S. M. Hu, X. T. Wu, Crystengcomm 2013, 15, 2120-2126.

DOI:10.1039/c2ce26461g

35. B. Isci, S. Uysal, J. Incl. Phenom. Macro. 2018, 92, 281-299. DOI:10.1007/s10847-018-0844-7

36. N. K. Chaudhary, P. Mishra, Bioinorg. Chem. Appl. 2017, Article ID 6927675, 1-13. DOI:10.1155/2017/6927675

37. F. Mendizabal, C. Olea-Azar, G. Zapata-Torres, F. Eisner, J. Mol. Struc. Theochem 2001, 543, 23-37.

DOI:10.1016/S0166-1280(00)00828-9

38. R. A. Polunin, N. P. Burkovskaya, S. V. Kolotilov, M. A. Kiskin, A. S. Bogomyakov, S. A. Sotnik, I. L. Eremenko, Russ. Chem. Bull. 2014, 63, 252-266.

DOI:10.1007/s11172-014-0421-1

39. R. A. Polunin, N. P. Burkovskaya, J. A. Satska, S. V. Kolotilov, M. A. Kiskin, G. G. Aleksandrov, O. Cador, L. Ouahab, I. L. Eremenko, V. V. Pavlishchuk, Inorg. Chem. 2015, 54, 52325238. DOI:10.1021/acs.inorgchem.5b00179

40. R. Shanmugakala, P. Tharmaraj, C. D. Sheela, N. Chidambaranathan, Med. Chem. Res. 2014, 23, 329-342.

DOI:10.1007/s00044-013-0634-0

41. B. Kebede, N. Retta, V. J. T. Raju, Y. Chebude, Transit. Metal Chem. 2006, 31, 19-26.

DOI:10.1007/s11243-005-6301-7

42. Z. E. Koc, S. Uysal, J. Inorg. Organomet. Polym. 2011, 21, 400-406.

43. C. Gao, D. Yan, Prog. Polym. Sci. 2004, 29, 183-275. DOI:10.1016/j.progpolymsci.2003.12.002

44. S. S. Mahapatra, N. Karak, Polym. Degrad. Stabil. 2007, 92, 947-955. DOI:10.1016/j.polymdegradstab.2007.03.012

\section{Povzetek}

2,4-diamino-6-metil-1,3,5-triazin (acetogvanamin) smo uporabili kot izhodno spojino. 2,4-diamino-6-metil-1,3,5-triazin smo refluktirali $\mathrm{z}$ glutaraldehidom in tereftalaldehidom $\mathrm{v}$ acetonitrilu. $\mathrm{S}$ to kondenzacijsko reakcijo smo pripravili polimerne ligande, ki vsebujejo s-triazin (IV in V). Te polimere smo analizirali $\mathrm{z}^{1} \mathrm{H}$ NMR, FT-IR in elementno analizo. V naslednji stopnji smo pripravili polimerne kovinske komplekse $\left(\mathrm{Co}^{2+}, \mathrm{Ni}^{2+}\right.$ in $\left.\mathrm{Cu}^{2+}\right)(\mathrm{VI}-\mathrm{XI}) \mathrm{z} \mathrm{reakcijo} \mathrm{z} \mathrm{CoCl}_{2} \cdot 6 \mathrm{H}_{2} \mathrm{O}$, $\mathrm{NiCl}_{2} \cdot 6 \mathrm{H}_{2} \mathrm{O}$ in $\mathrm{CuCl}_{2} \cdot 2 \mathrm{H}_{2} \mathrm{O}$ pri $60^{\circ} \mathrm{C}$ v etanolu. Strukture teh polimerov smo določili z uporabo FT-IR, elementne analize in analize magnetne susceptibilnosti. Stopnjo polimerizacije polimernih ligandov smo določili $\mathrm{z}$ molekulsko maso določeno $\mathrm{z}$ viskozimetrijo.

Except when otherwise noted, articles in this journal are published under the terms and conditions of the Creative Commons Attribution 4.0 International License 